\title{
Black carbon in snow in the upper Himalayan Khumbu Valley, Nepal: observations and modeling of the impact on snow albedo, melting, and radiative forcing
}

\author{
H.-W. Jacobi ${ }^{1,2}$, S. Lim ${ }^{1,2}$, M. Ménégoz ${ }^{1,2, *}$, P. Ginot ${ }^{2,3,4}$, P. Laj ${ }^{1,2}$, P. Bonasoni ${ }^{5}$, P. Stocchi ${ }^{5}$, A. Marinoni ${ }^{5,6}$, and \\ Y. Arnaud ${ }^{7,8}$ \\ ${ }^{1}$ Laboratoire de Glaciologie et Géophysique de l'Environnement, Univ. Grenoble Alpes, Grenoble, France \\ ${ }^{2}$ Laboratoire de Glaciologie et Géophysique de l'Environnement, CNRS, Grenoble, France \\ ${ }^{3}$ Observatoire des Sciences de l'Univers de Grenoble, Univ. Grenoble Alpes, Grenoble, France \\ ${ }^{4}$ Observatoire des Sciences de l'Univers de Grenoble, IRD, 38000 Grenoble, France \\ ${ }^{5}$ CNR-ISAC-Institute of Atmospheric Sciences and Climate, Bologna, Italy \\ ${ }^{6}$ EV-K2-CNR Committee, Bergamo, Italy \\ ${ }^{7}$ Laboratoire d'étude des Transferts en Hydrologie et Environnement, Univ. Grenoble Alpes, Grenoble, France \\ ${ }^{8}$ Laboratoire d'étude des Transferts en Hydrologie et Environnement, IRD, Grenoble, France \\ *now at: Institut Català de Ciències del Clima - IC3, Barcelona, Spain
}

Correspondence to: H.-W. Jacobi (hans-werner.jacobi@ujf-grenoble.fr)

Received: 11 July 2014 - Published in The Cryosphere Discuss.: 8 October 2014

Revised: 4 June 2015 - Accepted: 9 July 2015 - Published: 21 August 2015

\begin{abstract}
Black carbon (BC) in snow in the Himalayas has recently attracted considerable interest due to its impact on snow albedo, snow and glacier melting, regional climate and water resources. A single particle soot photometer (SP2) instrument was used to measure refractory BC (rBC) in a series of surface snow samples collected in the upper Khumbu Valley, Nepal between November 2009 and February 2012. The obtained time series indicates annual cycles with maximum rBC concentrations before the onset of the monsoon season and fast decreases during the monsoon period. Detected concentrations ranged from a few up to $70 \mathrm{ppb}$ with rather large uncertainties due to the handling of the samples. Detailed modeling of the snowpack, including the detected range and an estimated upper limit of $\mathrm{BC}$ concentrations, was performed to study the role of BC in the seasonal snowpack. Simulations were performed for three winter seasons with the snowpack model Crocus, including a detailed description of the radiative transfer inside the snowpack. While the standard Crocus model strongly overestimates the height and the duration of the seasonal snowpack, a better calculation of the snow albedo with the new radiative transfer scheme enhanced the representation of the snow. However, the period
\end{abstract}

with snow on the ground without BC in the snow was still overestimated between 37 and 66 days, which was further diminished by 8 to $15 \%$ and more than $40 \%$ in the presence of 100 or $300 \mathrm{ppb}$ of BC. Compared to snow without $\mathrm{BC}$, the albedo is reduced on average by 0.027 and 0.060 in the presence of 100 and $300 \mathrm{ppb}$ BC. While the impact of increasing $\mathrm{BC}$ in the snow on the albedo was largest for clean snow, the impact on the local radiative forcing is the opposite. Here, increasing BC caused an even larger impact at higher $\mathrm{BC}$ concentrations. This effect is related to an accelerated melting of the snowpack caused by a more efficient metamorphism of the snow due to an increasing size of the snow grains with increasing $\mathrm{BC}$ concentrations. The melting of the winter snowpack was shifted by 3 to 10 and 17 to 27 days during the three winter seasons in the presence of 100 and $300 \mathrm{ppb}$ BC compared to clean snow, while the simulated annual local radiative forcing corresponds to 3 to 4.5 and 10.5 to $13.0 \mathrm{~W} \mathrm{~m}^{-2}$. An increased sublimation or evaporation of the snow reduces the simulated radiative forcing, leading to a net forcing that is lower by 0.5 to $1.5 \mathrm{~W} \mathrm{~m}^{-2}$, while the addition of $10 \mathrm{ppm}$ dust causes an increase of the radiative forcing between 2.5 and $3 \mathrm{~W} \mathrm{~m}^{-2}$. According to the simula- 
tions, $7.5 \mathrm{ppm}$ of dust has an effect equivalent to $100 \mathrm{ppb}$ of $\mathrm{BC}$ concerning the impact on the melting of the snowpack and the local radiative forcing.

\section{Introduction}

Black carbon (BC) constitutes the most important lightabsorbing aerosol in the atmosphere, where it contributes to the warming of the atmosphere (Bond et al., 2013). It further affects cloud formation either acting as cloud nuclei or increasing the evaporation rates in cloudy layers. It is formed during incomplete combustion processes and mainly emitted due to natural and anthropogenic sources like biomass burning or fossil fuel and biofuel combustion (Bond et al., 2013). If $B C$ is incorporated in snow, it can lead to further warming due to its impact on the albedo of snow and ice, causing an accelerated melting (e.g., Hansen and Nazarenko, 2004; Flanner et al., 2007; Ménégoz et al., 2014). BC is also a strong pollutant, dangerous for human health and the environment, and is considered an important short-lived climate forcer. Therefore, reductions in $\mathrm{BC}$ emissions can potentially lead to a fast climate response, in particular in regions where elevated $\mathrm{BC}$ concentrations are observed. The global annual climate forcing of $\mathrm{BC}$ in the atmosphere and in the snow remains uncertain with the most recent estimates ranging from $+0.64( \pm 0.4)$ to $+1.1(\sim \pm 1) \mathrm{W} \mathrm{m}^{-2}$ (Stocker et al., 2013; Bond et al., 2013).

Since regional warming due to $\mathrm{BC}$ can be much stronger than the global average, the Himalayas have become of great interest. The extended cryosphere in the high-altitude regions of the Himalayas including numerous glaciers (Kääb et al., 2012) and large snow-covered regions (Ménégoz et al., 2013a) is expected to be especially vulnerable because of high radiation intensities and the vicinity of large anthropogenic BC sources on the Indian subcontinent or in Southeast Asia. Xu et al. (2009) proposed that BC in snow contributes to the retreat of glaciers observed in parts of the Himalayas, while Ramanathan et al. (2007) suggested that BC transported to the Himalayas contributed to the melting of the snow. If $\mathrm{BC}$ has an impact on the glacier mass balance as well as on the timing of the run-off formation due to the snow melt in springtime, this would have implications on the hydrological cycle, water resources, hydropower generation, and agriculture in the downstream regions, possibly affecting the living conditions of a population of more than a billion people (e.g., Immerzeel et al., 2010). Changes in the cryosphere may further modify sensible and latent heat fluxes, affecting also the Asian monsoon (Lau and Kim, 2006; Qian et al., 2011).

Measurements at the Nepal Climate Observatory at Pyramid (NCO-P) carried out since 2006 at $5079 \mathrm{~m}$ a.s.l. have confirmed that aerosols including $\mathrm{BC}$ can effectively be transported from the sources to high-altitude regions of the Himalayas (Bonasoni et al., 2010; Marinoni et al., 2010).
Ice cores and surface snow samples from different locations in the Himalayas (Ming et al., 2008; Kaspari et al., 2011; Ginot et al., 2014) and on the Tibetan Plateau (Ming et al., 2009; Xu et al., 2009) demonstrated that BC and other absorbing impurities like dust are efficiently incorporated into the snow. Based on ice core data, reductions in the snow albedo were estimated (Ginot et al., 2014), assuming that the profile of the ice core concentration directly corresponds to the evolution of the $\mathrm{BC}$ concentration in the surface snow layer. Furthermore, the transport of $\mathrm{BC}$ from the source regions and its deposition to the snow was calculated using different global transport and chemistry models (Flanner et al., 2007; Kopacz et al., 2011; Ménégoz et al., 2014). These studies resulted in an estimated annual radiative forcing due to $\mathrm{BC}$ in snow between 7 and $12 \mathrm{~W} \mathrm{~m}^{-2}$ close to the Mt. Everest (Kopacz et al., 2011) and between 1 and $4 \mathrm{~W} \mathrm{~m}^{-2}$ in the snow-covered areas of the Himalayas (Ménégoz et al, 2014), while peak values in the monthly radiative forcing exceeded 15 to $25 \mathrm{~W} \mathrm{~m}^{-2}$ for some parts of the Tibetan Plateau (Flanner et al., 2007; Kopacz et al., 2011; Qian et al., 2011). However, large uncertainties in the calculated radiative forcing remain because of the low spatial resolution of the global models used, preventing a precise representation of the high-altitude regions and the pronounced topography of the mountain range. These model limitations constrain a multitude of simulated processes including local-scale flow, transport of water vapor and aerosols, precipitation, and snow cover formation and melting (Ménégoz et al., 2013a), which are crucial in obtaining a correct radiative forcing for $\mathrm{BC}$ in snow. It has been demonstrated that these deficits can cause an overestimation of the snow cover on the Tibetan Plateau, producing also a likely positive bias in the estimated radiative forcing for BC in snow in this region (Ménégoz et al., 2013a, 2014). Moreover, some models generate significantly higher $\mathrm{BC}$ in snow concentrations compared to the few available observations in the Himalayas and on the Tibetan Plateau (Flanner et al., 2007; Ménégoz et al., 2014). However, the limited BC in snow measurements make it difficult to get a reliable idea of the spatial distribution, seasonal cycle, and interannual variability of $\mathrm{BC}$ in snow in this vast and complex region, greatly diminishing our capability to validate model results (Qian et al., 2011).

It is well known that $\mathrm{BC}$ is not the only absorbing impurity in the snow in the high-altitude region of Tibet and the Himalayas. High concentrations of dust have been observed in the atmosphere (e.g., Carrico et al., 2003; Duchi et al., 2014) and in ice cores (Thompson et al., 2000; Kaspari et al., 2011; Ginot et al., 2014). Duchi et al. (2014) reported the frequency of dust transport events at NCO-P with a maximum during the pre-monsoon period causing on average a 10 -fold increase of $\mathrm{PM}_{10}$ in the atmosphere, compared to days without identified dust events. While the absorption of solar radiation due to dust is much less efficient compared to $\mathrm{BC}$, this is at least partly compensated for by much higher concentrations. Ginot et al. (2014) found dust concentrations up to 
almost $70 \mathrm{ppm}$ and an average concentration throughout all seasons around $10 \mathrm{ppm}$ in an ice core from the Mera glacier, which is significantly higher than any observed concentration of BC or elemental carbon (EC) in snow in this region (Ming et al., 2008, 2009; Xu et al., 2006; Kaspari et al., 2011; Ginot et al., 2014).

The presence of absorbers in the snow has multiple impacts on the properties of the snow, which finally contribute to the radiative forcing (Painter et al., 2007; Flanner et al., 2007). The first order impact is related to the direct reduction of the snow albedo due to the incorporation of the absorbers in the snow. A second order impact is linked to the fact that the reduction of the albedo leads to a stronger warming of the snowpack compared to the clean snow, causing a faster metamorphism (or snow aging) and, thus, a more efficient growing of the snow crystals. Since larger snow crystals cause a reduced albedo, this effect leads to a further reduction of the albedo of the snowpack. Nevertheless, the forcing related to changes in the albedo remains small compared to the positive radiative forcing induced by the earlier exposition of the underlying soil caused by an accelerated melting of the warmer snow containing BC. To study these multiple impacts of the absorbing impurities on the processes and properties of the snow in detail, a detailed physical snowpack model like Crocus with sufficient complexity is needed (Brun et al., 1989, 1992; Vionnet et al., 2012). Crocus is capable of calculating the internal energy budget of the snowpack, to resolve temperature gradients inside the snowpack, and to simulate the metamorphism of the snow. However, the standard model version does not allow considering absorbing impurities like $\mathrm{BC}$ or dust for the calculation of the albedo.

Here, we report multi-annual measurements of BC in surface snow sampled on the southern slopes of the Himalayas close to NCO-P. We compare the snow concentrations with simultaneous atmospheric measurements to investigate the role of wet and dry deposition. Moreover, we present the Crocus snowpack model with an upgraded radiative transfer scheme to study the impact of $\mathrm{BC}$ and dust in snow. Forced with 3 years of meteorological observations from the Pyramid International Laboratory (close to NCO-P) and with observed $\mathrm{BC}$ and dust concentrations, the model was used to study the impact of the two absorbing impurities on snow metamorphism, melting, and local radiative forcing. The model results including sensitivities of the melting and radiative forcing due to the presence of $\mathrm{BC}$ and/or dust in the snow are presented and compared to previous large-scale model studies.

\section{Methods}

\subsection{Snow sampling}

56 samples of surface snow were collected in Nepal during the period from 13 November 2009 to 29 February
2012 at three different locations in the Khumbu region south of the Mount Everest: At NCO-P $\left(27.96^{\circ} \mathrm{N}, 86.81^{\circ} \mathrm{E}\right.$; $5079 \mathrm{~m}$ a.s.1.) and on the glaciers Changri Nup $\left(27.98^{\circ} \mathrm{N}\right.$, $86.76^{\circ} \mathrm{E} ; 5700 \mathrm{~m}$ a.s.1.) and Pokalde $\left(27.93^{\circ} \mathrm{N} ; 86.83^{\circ} \mathrm{E}\right.$; $5600 \mathrm{~m}$ a.s.1.; Fig. 1). In most cases, snow from the top layer $(\leq 10 \mathrm{~cm})$ was collected and transported to France. Using field notes, observed precipitation, and snow height at NCO$\mathrm{P}, 51$ of the available snow samples were classified into fresh snow (i.e., snowfall within $24 \mathrm{~h}$ before sampling) and old snow. Five samples remained unclassified.

\subsection{Snow sample analysis and handling}

The snow samples were analyzed using a Single Particle Soot Photometer (SP2, Droplet Measurement Technologies, US) to determine refractory $\mathrm{BC}(\mathrm{rBC})$ particles. Details of the analytical procedure are described in Lim et al. (2014). The SP2 applies a laser-induced incandescence technique to measure the mass of individual $\mathrm{rBC}$ particles (Schwarz et al., 2006), independent of particle morphology and light-scattering coating materials (Moteki and Kondo, 2007, 2010). Each rBC particle passes through the laser beam intracavity, where it absorbs light, reaches a vaporization temperature, at which it incandesces, and emits visible thermal radiation proportional to the mass of the individual particles. The SP2 is highly sensitive to $\mathrm{rBC}$ particles, but much less to other absorbing particles like dust. It was calibrated with fullerene soot (Alfa Aesar Inc., USA), a standard BC material of known single particle mass aggregating primary particles with graphitic structure. A new nebulizer (APEX-Q, Elemental Scientific Inc., Omaha, USA) was used to increase the efficiency of the transfer of the rBC particles in the snow into the gas phase. The $\mathrm{rBC}$ losses during aerosolization were determined using eight liquid Aquadag ${ }^{\circledR}$ standards, resulting in an average efficiency of $56 \%$, which was applied to all BC concentrations reported here.

All snow samples melted during transport from the field sites to France. They were stored at $<5{ }^{\circ} \mathrm{C}$ until analysis in April 2012. Before analysis, the samples were sonicated for $15 \mathrm{~min}$ to minimize rBC losses on the container wall. Five selected samples were reanalyzed almost 2 years later to evaluate the rBC particle loss during long-term storage of the samples in liquid form. The samples showed decreases in detected $\mathrm{rBC}$ concentrations between 0 and $80 \%$, which is probably related to particles' attachment on the container wall and the agglomeration of particles. The loss during storage was not straightforward and seemed to be highly variable depending on storage time and $\mathrm{rBC}$ concentration. Therefore, all measured concentrations are presented here without any further correction for potential rBC losses during transport or storage and should be considered as minimum values. 


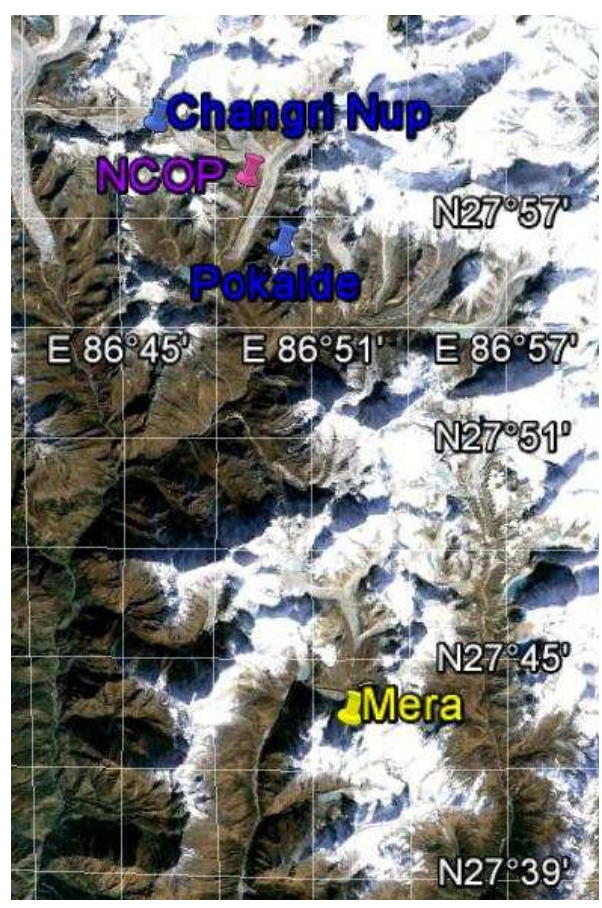

Figure 1. Google earth map indicating the field sites NCO-P, Pyramid, Changri Nup, and Pokalde. Also shown is the drilling site of the Mera ice core (Ginot et al., 2013).

\subsection{Meteorological data and atmospheric BC}

Meteorological parameters have been recorded at Pyramid International Laboratory close to NCO-P since 1994, and radiation and snow depth since 2002. Moreover, continuous measurements of atmospheric $\mathrm{BC}$ concentrations have been performed at NCO-P using a Multiangle Absorption Photometer since 2006. Further details of the instrument setup and the calculation of equivalent $\mathrm{BC}$ concentrations are described by Marinoni et al. (2010).

\subsection{Modeling}

Simulations were performed with the one-dimensional multilayer physical snowpack model Crocus (Brun et al., 1989, 1992; Vionnet et al., 2012), which explicitly solves the surface mass and energy budgets, taking into account heat diffusion, transfer of radiation, densification, sublimation, condensation, melting, and liquid water percolation in the snow. The model is forced using meteorological data like air temperature, wind speed, relative humidity, precipitation quantity and phase, incoming direct and diffuse solar radiation, incoming long-wave radiation, and cloud cover. The simulated snowpack consists of multiple homogeneous horizontal layers, which are established according to snowfall events undergoing transformation related to a metamorphism scheme. It calculates physical properties of each modeled snow layer including thickness, temperature, density, liquid water con- tent, snow type, grain size, and age. The model further computes budgets of the snowpack like total height, run-off, latent and sensible heat fluxes, and fluxes of infrared and shortwave radiation.

In the Crocus standard version, the albedo is not prescribed, but parameterized using the snow grain size and age of only the uppermost layer of the snowpack (Vionnet et al., 2012). The albedo is subsequently applied to calculate the absorbed amount of incoming radiation, while the penetration of the absorbed radiation is simulated using absorption coefficients estimated from the density and grain size of each snowpack layer.

The standard albedo parameterization does not offer the possibility to account for the presence of absorbing impurities. In order to study the impact of BC and dust on the snowpack with Crocus, we implemented a physically-based radiative transfer scheme without prescribed albedo values. We employed the theory of Wiscombe and Warren (1980) and Warren and Wiscombe (1980) based on a module previously used in the land surface scheme ORCHIDEE for simulations with the global model LMDZ (Krinner et al., 2006; Ménégoz et al., 2013b, 2014). Starting with a fixed soil albedo, the albedo for diffuse radiation is calculated at the top of the bottom snow layer using the snow water equivalent (SWE), grain size, and $\mathrm{BC}$ and dust concentrations of this layer. The same procedure is applied for the overlying snow layers until the surface layer is reached. For the surface layer, the albedo for direct radiation is calculated, taking into account the solar zenith angle. The albedo for diffuse and direct radiation is separately combined with the incoming direct and diffuse radiation to calculate the overall amount of absorbed radiation. Since the albedo calculation for the diffuse radiation delivers also absorption coefficients, these are used to calculate the amount of radiation energy absorbed in each snow layer, assuming that within the top snow layer all direct radiation was transformed into diffuse radiation. We used the same optical properties for ice like Krinner et al. (2006). For $\mathrm{BC}$ we assumed a log-normal size distribution with a median number radius of $11.8 \mathrm{~nm}$, a density of $1 \mathrm{~g} \mathrm{~cm}^{-3}$, and a refractive index of $\mathrm{m}=1.75-0.45 i$ (Ménégoz et al., 2013b); for dust a log-normal size distribution was used with a median mass diameter of $2 \mu \mathrm{m}$ and a refractive index according to its hematite content (Krinner et al., 2006). Using these typical, but fixed properties for BC and dust may lead to an underestimation of the impact of the aerosols on the simulated albedo, mainly because the model only considers externally mixed aerosols (Flanner et al., 2012). Nevertheless, the derived BC mass absorption cross section of $7.6 \mathrm{~m}^{2} \mathrm{~g}^{-1}$ at $545 \mathrm{~nm}$ corresponds to previously published values (Bond and Bergstrom, 2006; Flanner et al., 2007). Since the standard version of Crocus considers three different wavelength ranges for the albedo and the absorption coefficient, the values derived from the radiative transfer module were also averaged for the same bands from 300 to $800 \mathrm{~nm}, 800 \mathrm{~nm}$ to $1.5 \mu \mathrm{m}$, and 1.5 to $2.8 \mu \mathrm{m}$. 
For our simulations we used observations covering the period August 2004 to July 2007 obtained at an altitude of $5050 \mathrm{~m}$ a.s.1. at Pyramid Laboratory to construct the needed forcing data. Quality controlled $1 \mathrm{~h}$ averages were used for temperature, wind speed, humidity, and radiation without further correction. However, it is well known that the observed precipitation significantly underestimates solid precipitation (Bonasoni et al., 2010; Shrestha et al., 2012). Accordingly, the observed snow height shows for several instances strong increases, while no simultaneous precipitation was recorded as already described by Shrestha et al. (2012). As a result, preliminary simulations with the standard and upgraded Crocus model with the recorded precipitation did not lead to the build-up of a significant snowpack. Therefore, a corrected precipitation data set based on the observed snow height was constructed and employed for all further snowpack simulations. If the snow height showed an increase, while no precipitation was detected, the increase in snow height was transformed into accumulation using a density of fresh snow of $0.08 \mathrm{~g} \mathrm{~cm}^{-3}$. Using such a density led to a good agreement of simulated and observed increases in the snowpack height during the 2004/2005 winter season. Since the detector of the snowpack height showed regular fluctuations around $\pm 1 \mathrm{~cm}$, only increases in height larger than $1 \mathrm{~cm}$ were considered (Shrestha et al., 2012). In addition, the snow height sensor recorded several peaks with strong increases in height and subsequent large decreases of several tens of $\mathrm{cm}$ within hours or days. These peaks were removed after visual inspection of the time series. Finally, the phase of the precipitation was estimated using observed air temperatures with only solid precipitation at $T_{\text {air }}<0^{\circ} \mathrm{C}$, only liquid precipitation at $T_{\text {air }}>+2{ }^{\circ} \mathrm{C}$, and mixed phase precipitation with $50 \%$ solid precipitation in the remaining temperature range. A comparison of recorded and corrected time series of precipitation is shown in the Supplementary material (Figs. S1a, b, and c in the Supplement). After applying the corrections the estimated total annual precipitation corresponds to $491.7 \mathrm{~mm}$ (41\% solid precipitation), $423.8 \mathrm{~mm}$ (55\% solid precipitation), and $454.8 \mathrm{~mm}$ (51\% solid precipitation) for the years 2004/2005, 2005/2006, and 2006/2007, compared to the recorded total precipitation of only 360 (2004/2005), 231 (2005/2006), and $304 \mathrm{~mm}$ (2006/2007). The corrected annual values are in excellent agreement with an estimated multi-year average of the annual precipitation of $\sim 450 \mathrm{~mm}$ at NCO-P for the period 1994 to 2013 (Salerno et al., 2015). Due to the uncertainty in the estimated solid precipitation, the model sensitivity was tested using differing meteorological forcing data for the year 2004/2005. These data sets were generated with different thresholds for the solid, mixed phase, and liquid precipitation varying from 0 to $4{ }^{\circ} \mathrm{C}$. They are described in the Supplementary material and showed maximum and minimum values of solid precipitation ranging from 30 to $56 \%$ of the total precipitation (Table S1 in the Supplement).
In the Crocus simulations, the fraction of cloud cover is used to determine the contributions of direct and diffuse radiation to the total incoming radiation. For the simulations, the cloud cover fraction was set to 0 (denoting clear sky) if the ratio between observed and theoretical incoming solar radiation was larger than 0.8 , to 0.5 (denoting cloudy) if the ratio was between 0.2 and 0.8 , and to 1 (denoting overcast) if the ratio was below 0.2 . Based on these derived cloud fractions, the observed incoming shortwave radiation was divided into direct and diffuse radiation using the same parameterizations as in the Crocus model. As a result the total incoming radiation for the forcing of the model corresponds exactly to the measured values. The estimated cloud cover only affects the distribution between direct and diffuse radiation, which has a slight impact on the calculation of the albedo as described above.

\section{Results and discussion}

\subsection{BC concentrations in surface snow}

Observed $\mathrm{rBC}$ concentrations are highly variable ranging from less than 0.1 to more than $70 \mathrm{ppb}$ (Fig. 2). Calculated average and median concentrations of all samples correspond to 10 and $1.5 \mathrm{ppb}$. As described in the Methods section, the reported concentrations are potentially underestimating the real BC concentrations. Nevertheless, the increases in the concentrations during the dry seasons 2009/2010 and $2010 / 2011$ are well beyond the uncertainty of the measurements, which can be as high as a factor of 5. Despite this uncertainty and the high variability, we conclude that the concentrations follow a seasonal cycle with low values in the post-monsoon and winter season and higher concentrations in the pre-monsoon, culminating at maximum concentrations before the onset of the monsoon.

Regarding snow types, we obtained somewhat higher concentrations in the old snow samples (average $15 \mathrm{ppb}$, median $3 \mathrm{ppb}$ ) compared to the fresh snow samples, with average and median concentrations of 5 and $1.3 \mathrm{ppb}$. However, these differences as well as differences between the sampling sites remain questionable because they are small compared to the uncertainty of the $\mathrm{rBC}$ concentrations.

Lower rBC concentrations were measured by Kaspari et al. (2011) in an ice core from the East Rongbuk Glacier at $6500 \mathrm{~m}$ a.s.1. close to Mt. Everest using the same analytical method. They found average concentrations of $(0.7 \pm 0.1) \mathrm{ppb}$ for the period 1975 to 2000 and a maximum of $32 \mathrm{ppb}$. However, the same uncertainty in the measured rBC concentrations as for our samples due to the sample handling applies to the data reported by Kaspari et al. (2011).

Finally, the concentrations reported here are lower compared to the results for EC obtained with the thermo-optical method for snow and ice core samples from the high-altitude region of the Himalayas and the Tibetan Plateau. For ex- 


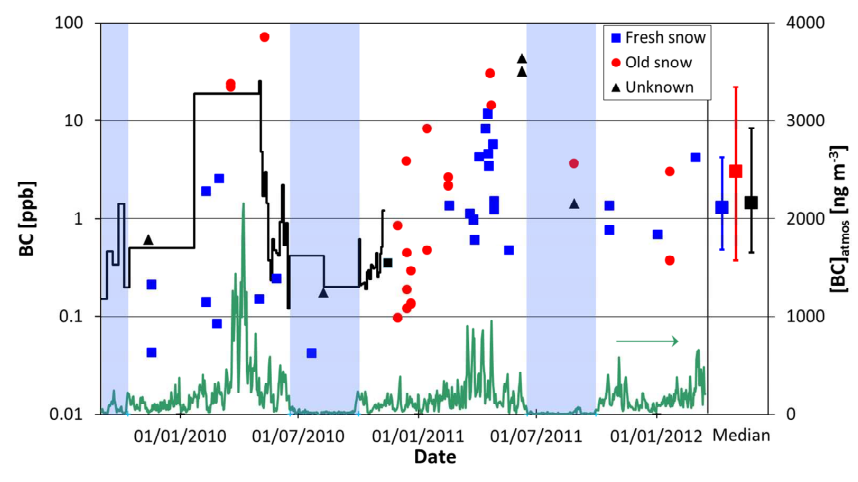

Figure 2. Time series of measured BC concentration in surface snow samples from the Khumbu Valley. The samples were classified into fresh (blue), old (red), and unknown snow (black). The symbols on the right show median concentrations for fresh (blue), old (red), and all snow samples (black). The error bars correspond to the 25 th and 75 th percentile. Shaded blue areas indicate the monsoon periods 2009, 2010, and 2011 over Nepal according to Tyagi et al. (2010, 2011) and Tyagi and Pai (2012). The black line corresponds to the $\mathrm{BC}$ concentration for the period between 1 September 2009 and 8 November 2010 season determined in the Mera ice core (Ginot et al., 2013) with the surface snow concentration from 11 November 2010 shown as black squares. The green line shows the atmospheric BC concentrations measured at NCO-P.

ample, Ming et al. $(2008,2009)$ reported EC concentrations between 2 and $981 \mathrm{ppb}$ in surface snow samples from West China for the period 2004 to 2006 and average concentrations around $20 \mathrm{ppb}$ in an ice core section covering 1995-2002 extracted from the East Rongbuk Glacier. Higher EC values compare well to a comparison of $\mathrm{EC}$ and $\mathrm{rBC}$ measurements using the same snow samples from Nepal, leading to an average $\mathrm{EC} / \mathrm{rBC}$ ratio of 3.4 (Lim et al., 2014). In contrast, comparable results were obtained by Xu et al. (2006), who reported a range of EC concentration between 4 and $80 \mathrm{ppb}$ in surface and fresh snow samples collected between 2001 and 2004 on various glaciers on the Tibetan Plateau.

The seasonal cycle in the surface snow corresponds well to the $\mathrm{rBC}$ concentration profile measured in an ice core retrieved from the Mera glacier at $6376 \mathrm{~m}$ a.s.l. (Ginot et al., 2014). While minimum rBC concentrations were similar, maximum concentrations in the ice core remained smaller probably due to lower deposition at higher altitudes. For comparison, the results of the overlapping period in the ice core and surface snow samples are shown in Fig. 2. Low concentrations of $0.35 \mathrm{ppb}$ were found in the surface snow corresponding to the November layer, which is absent in the rest of the ice core due to efficient erosion during the following winter season.

The surface snow samples as well as the Mera ice core reveal the impact of wet and dry deposition responsible for the incorporation of $\mathrm{BC}$ into the snow and strong links with the seasonal cycle of precipitation and atmospheric $\mathrm{BC}$ concentrations as recorded at NCO-P (Figs. S1a, b, c, 2). It seems that wet deposition due to the accumulation of fresh snow leads to relatively small concentrations of $\mathrm{rBC}$ around $1 \mathrm{ppb}$. However, in the case of snowfall during the premonsoon season, when atmospheric $\mathrm{BC}$ concentrations are high, $\mathrm{rBC}$ concentrations in fresh snow can increase to more than $10 \mathrm{ppb}$. Additional dry deposition of $\mathrm{BC}$ seems to have a relatively small impact during the winter period and old snow exposed at the surface contains relatively low $\mathrm{BC}$ amounts. Maximum BC concentrations are reached again in the premonsoon season potentially combining large inputs due to wet and dry deposition. Yasunari et al. (2013) estimated BC concentrations in surface snow using deposition velocities calculated with meteorological measurements at NCO-P and atmospheric measurements of equivalent BC. Considering only dry deposition they obtained concentrations between 90 and $130 \mathrm{ppb}$ in old snow for a continuous snowpack until end of May. The observed rBC maxima are somewhat lower than these values, possibly because the seasonal snowpack at NCO-P melts earlier and some of the BC may be lost due to the handling of the samples.

\subsection{Snowpack modeling: standard vs. upgraded model}

Although the Crocus model has so far been used in different alpine and polar regions (e.g., Jacobi et al., 2010; Brun et al., 2011; Vionnet et al., 2012), it has to our knowledge never been applied to simulate the seasonal snowpack in the Himalayas. Recently, a modified version of the model was employed to simulate the snow on top of a debriscovered glacier in the Khumbu Valley (Lejeune et al., 2013). To examine the performance of the two model versions, we first compared the results of the standard Crocus model and the upgraded version including the radiative transfer for the seasons 2004/2005, 2005/2006, and 2006/2007, applying the forcing data based on the observations at the Pyramid site. The simulated snowpack heights for the season 2004/2005 are shown in Fig. 3 (for the seasons 2005/2006 and 2006/2007 in the Supplement, Figs. S2a and b). In all three winter seasons, the standard Crocus model largely overestimates the period with snow on the ground (Figs. 3, S2a and $b$ ). For example, Crocus predicts the formation of a continuous snowpack starting on 14 October 2004 and lasting until 4 January 2005 due to several small snowfall events in October and November. However, the snow height records and albedo measurements show that during this period the fresh snow regularly melts within a day after precipitation. The onset of the seasonal winter snowpack at the end of January 2005, corresponding to the longest period with continuous snow on the ground, is well represented by Crocus because the observed snowpack heights are used to construct the precipitation time series. In contrast, observed snowpack heights start to decrease mid-February 2005 and are interrupted only by additional accumulation in mid-March, until the snow disappears before the end of March 2005. In contrast, the winter snowpack remains intact in the Crocus simu- 

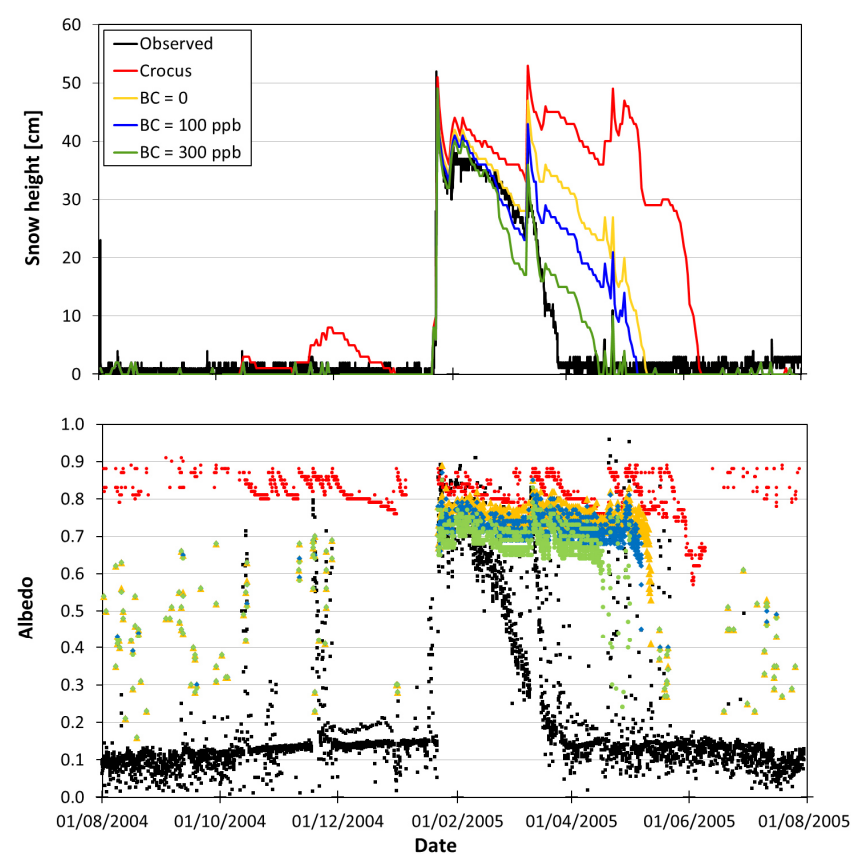

Figure 3. Comparison of observed (black) and simulated snowpack heights (top) and albedo (bottom) at NCO-P for the winter season 2004/2005. Simulations were performed with the standard crocus model (red) and with the upgraded model including radiative transfer with constant BC concentrations of 0 (yellow), 100 (blue), and $300 \mathrm{ppb}$ (green). Snowpack heights simulated with the upgraded model are indistinguishable for the different BC concentrations until late January and after mid-May.

lations until end of May 2005, while it melts completely only on 10 June 2005. In summary, while the observed total period with snow on the ground (defined as an observed snow height $>2 \mathrm{~cm}$ ) corresponds to 78 days, the standard Crocus model predicts a period of 238 days with snow on the ground. The period with snow on the ground is similarly overestimated by Crocus for the years 2005/2006 and 2006/07 with +91 and +157 days compared to the observations (Figs. S2a and b).

The positive bias is strongly reduced using the upgraded Crocus model including the radiative transfer even without considering any absorbing impurity. During these simulations the snowpack shows a much stronger dynamic with faster drops in the snow height compared to the standard model. Moreover, fresh snow in the fall and early winter season is not conserved for more than $24 \mathrm{~h}$ (Figs. 3 and S2a) and melts in agreement with the observed snow heights (Fig. S2b). The simulated duration of the snow cover is reduced between 54 and 103 days compared to the standard Crocus model. Nevertheless, the period with snow on the ground is still overestimated by 57, 37, and 66 days for the years 2004/2005, 2005/2006, and 2006/2007 relative to the observations.

The different behavior of the standard and the upgraded model is related to the calculated albedo and the correspond- ing energy absorbed by the snowpack. Figure 3 shows a comparison of the simulated albedo for 2004/2005 together with observed albedo derived from the ratio of the up- and downwelling shortwave radiation. A large part of the differences between observed and simulated albedo concerning all model results is related to the overestimation of the simulated periods with snow. Apparently, the model delivers high albedo values for the period when snow is still present, while the observations correspond to the low values of the soil after the melting of the snow.

Figure 3 illustrates further differences in the simulated albedo of the two model versions and the impact of increasing the $\mathrm{BC}$ concentrations. In the standard model, the albedo rises with each precipitation event to values around 0.9 before it slowly decreases due to the albedo parameterization related to the aging of the snow. Since only the properties of the top snow layer are considered in the standard model, the simulated albedo is not affected by the thickness of the snowpack and the parameterized albedo is similar regardless of the snow height. In contrast, the effect of a thin snowpack is better reproduced by the upgraded model. Here, the SWE of each snowpack layer is an important variable and leads in the case of a thin snowpack to strongly reduced albedo values as can be seen in the cases of snowfall before December 2004 or after June 2005 (Fig. 3). During these events the simulated albedo remains between 0.2 and 0.7 , causing a stronger absorption of the incoming solar radiation and, thus, a complete melting of the snow.

In all model versions, the precipitation in late January leads to the formation of the seasonal winter snowpack (Fig. 2) with an albedo between 0.6 and 0.9. These albedo values of the fresh snow are relatively well reproduced by both model versions (Fig. 3). However, neither model captures the relatively strong decrease of the albedo to 0.3 until 10 March before a new snowfall event increases the observed albedo to more than 0.8 . In both model versions the overestimation of the period with snow on the ground is directly linked to the positive bias in the simulated albedo. Similar results are obtained for the years 2005/2006 and 2006/2007 (Figs. S3a and b). A statistical analysis of the comparison between observed and simulated albedo including bias, root mean squared errors (RMSE), and correlation coefficients for all three winter seasons is compiled in the Supplementary material (Table S2). The results show an improvement of the simulated albedo using the upgraded Crocus model, which improves further after increasing the $\mathrm{BC}$ concentrations from 0 to 100 or $300 \mathrm{ppb}$. On average for all three winter seasons, the bias and RMSE are below 0.11 and 0.18 in the best model runs, while the correlation coefficient is as high as 0.5 . Considering only the first month of each winter season, the bias and RMSE decrease to below 0.01 and 0.09 , while the correlation coefficient increases only slightly. Similarly, Shrestha et al. (2012) simulated a delayed melting of the snow and overestimated the springtime snow-covered area in the Dudhkoshi region with a three-layer snow model. 
They also attributed a large part of the model bias to the used simplified albedo parameterization. This corresponds well to results from previous snow model comparisons indicating that the albedo parameterization is a crucial component for snow models (Etchevers et al., 2004).

Although an important part of the positive bias in the albedo is reduced in the presence of absorbing impurities, strong differences between observed and simulated albedo remain, especially in the later part of the winter season including the melting period. Sensitivity runs with varying amounts of solid precipitations show only small differences in the snow-covered periods (Fig. S5 and S6) and in the simulated albedo. Moroever, the impact on the bias, RMSE, and correlation coefficients of the simulated albedo remained negligible (Table S3). Therefore, the uncertainty in the estimated precipitation cannot explain the overestimation of the snow-covered period and the albedo.

The statistical analysis of the simulated albedo indicates that the albedo values earlier in the season are better represented by the radiative transfer theory, while the fast decrease of the albedo during the melting period is still not captured by the model. These differences are further illustrated in Fig. 4, which shows daily averaged albedo values for two periods after fresh snowfall events. While the absolute observed albedo as well as its trend is reasonably well reproduced by the upgraded model for the winter season after 16 February 2007, the comparison for the melting period after 26 April 2006 still shows large deviations. These two periods are characterized by large differences in the average $\left(-11.8\right.$ vs. $\left.-2.5^{\circ} \mathrm{C}\right)$ and maximum air temperatures $(-2.6$ to $3.5^{\circ} \mathrm{C}$ ). These results demonstrate that the performance of the upgraded model is still limited during the melting of the snowpack. This may concern internal processes like the metamorphism of wet snow as well as meltwater formation and percolation, which are challenging to reproduce in snowpack models (e.g., Brun et al., 1992). Another important process currently not implemented in the model is the vertical redistribution of the absorbing impurities. Due to a range of processes like dry deposition, flushing out, or enrichment during melting, the absorbers may be concentrated in certain layers leading to potentially higher concentrations as encountered in the snow samples and further reducing the snow albedo. Nevertheless, a successful representation of such processes impacting impurities in the snow requires first an improved description of liquid water formation and movement inside the snowpack and can probably only be addressed in the next generation of snowpack models.

Differences between observations and simulations may also be related to the available observations. For example, the spatial variability of the meteorological as well as the snow conditions in the rugged terrain of the Himalayas may not be captured by the point measurements used here to drive and validate the snow model. The atmospheric and snow observations at the field site may only represent localized and nonideal conditions introducing additional variability that cannot
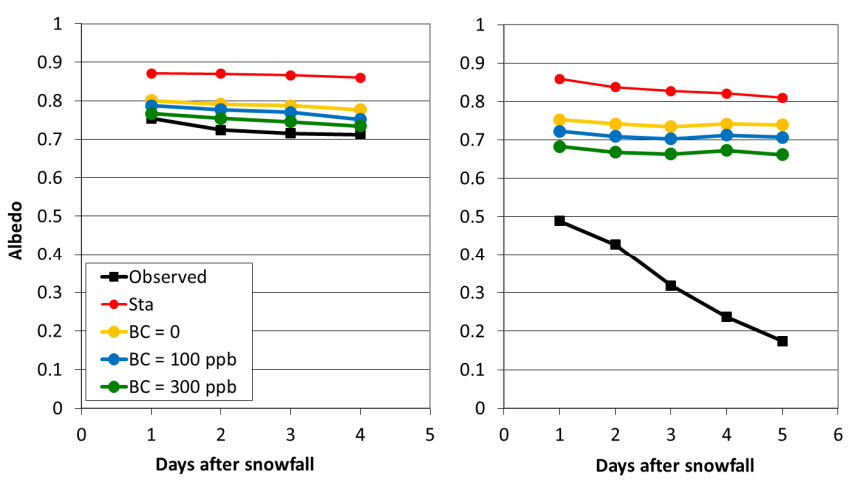

Figure 4. Comparison of observed (black) and simulated daily averages of the snow albedo at NCO-P for the period after 16 February 2007 (left) and 26 April 2006 (right). Simulations were performed with the standard Crocus model (red) and with the upgraded model including radiative transfer with constant $\mathrm{BC}$ concentrations of 0 (yellow), 100 (blue), and $300 \mathrm{ppb}$ (green).

be represented by the simulations. This variability as well as further uncertainties in the observations directly translate into errors in the snowpack simulations, contributing also to the differences between simulations and observations.

\subsection{Impact of BC on snow albedo}

Despite the uncertainty in the simulations during the melting period, we studied the simulated impact of $\mathrm{BC}$ present in the snow based on the runs with different $\mathrm{BC}$ concentrations. We selected concentrations of 100 and $300 \mathrm{ppb}$ covering the range of the maximum $\mathrm{BC}$ concentration reported here, including their uncertainty. Figure 5 shows the simulated albedo for the three different BC concentrations $(0,100$, and $300 \mathrm{ppb}$ ) during the period 21 to 31 January 2005 . Between 21 and 23 January, several snowfall events led to the initial formation of the winter snowpack. As a result, the observed albedo increased from values below 0.2 on 21 January to more than 0.8 the following day and to even higher values on 23 January. It followed a period of 7 days without further precipitation and slightly decreasing albedo values. Similar results are obtained in the simulations, during which a maximum albedo was reached early on 24 January with a subsequent decrease in the calculated albedo. Additional fresh snow during the night from 30 to 31 January increased the albedo values in the observations and simulations. Figure 5 shows that several short-term features in the observations are well reproduced in the simulations: the diurnal cycle of the albedo with morning and evening maxima (26 and 27 January), the continuous decrease on 24 January, or the unusual behavior on 28 January. The model is also capable of simulating a positive feedback loop between albedo, snow temperature, and grain size in the presence of $\mathrm{BC}$, referred to as the first indirect effect (Painter et al., 2007). Initial conditions in the snowpack with different $\mathrm{BC}$ concentrations are very sim- 


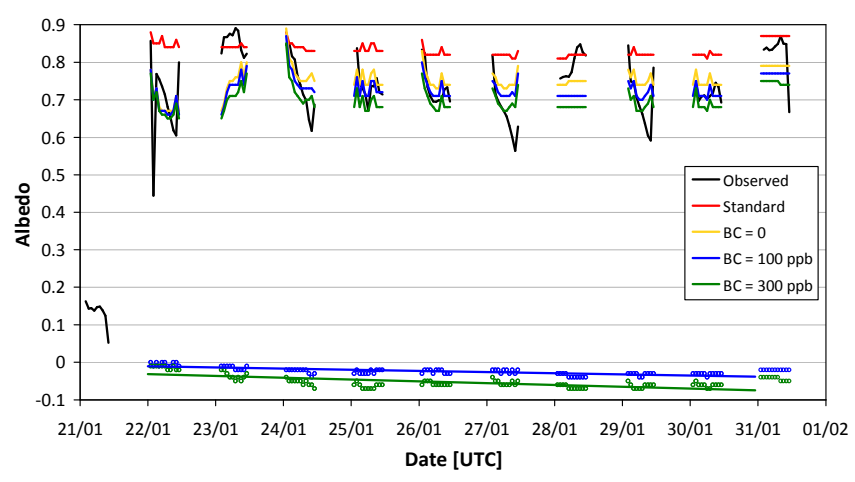

Figure 5. Comparison of observed (black) and simulated albedo at NCO-P for the period 22 to 31 January 2005. Model results are obtained with the upgraded model including radiative transfer with different BC concentrations: 0 (yellow), $100 \mathrm{ppb}$ (blue), and $300 \mathrm{ppb}$ (green). Circles at the bottom indicate the differences of the simulated albedo between $\mathrm{BC}=100 \mathrm{ppb}$ and 0 (blue) and $\mathrm{BC}=300 \mathrm{ppb}$ and 0 (green). Straight blue and green lines show the results obtained by linear regressions for the albedo differences during the period 22 to 30 January 2005.

ilar leading to almost indistinguishable albedo values on 22 January in all model runs. However, first small differences in the snowpack properties become apparent on 23 January (Table 1). While snow height, SWE, and average temperature are similar in all model runs, simulated snow temperatures in the top layer are slightly higher with $\mathrm{BC}$ present in the snow. For example, the presence of 100 and 300 ppb BC in the snow increases the temperature in the top $10 \mathrm{~cm}$ by 0.2 and $0.4 \mathrm{~K}$. The simulated averaged diameter of the snow grains is still very similar in all model runs with average diameters around $300 \mu \mathrm{m}$ and differences smaller than $5 \mu \mathrm{m}$. Nevertheless, they show already an increasing trend with increasing BC. On 30 January, this situation has changed with snow temperatures (average for the entire snowpack or for the top $10 \mathrm{~cm}$ ) that are at least $0.5 \mathrm{~K}$ higher in the presence of BC. During the same period, the simulated average grain diameter increased to 369,386 , and $400 \mu \mathrm{m}$, respectively, in the presence of 0,100 , and $300 \mathrm{ppb} \mathrm{BC}$ in the snow. These grain sizes still remain smaller than the average grain size of 418 to $475 \mu \mathrm{m}$ retrieved by Negi and Kokhanovsky (2011) using satellite data for a 7-day old snowpack in the upper Himalayas, which evolved at snowpack temperatures below $-20^{\circ} \mathrm{C}$.

Due to the faster-growing snow grains, the simulated albedo values decrease faster in the presence of $\mathrm{BC}$. The growing gap between the simulated albedo values with 100 and $300 \mathrm{ppb}$ compared to snow without $\mathrm{BC}$ is shown in Fig. 5. Due to the snow metamorphism, the albedo of the pure snow decreases on average by $\sim 0.004$ per day between 24 and 31 January. In the presence of 100 and $300 \mathrm{ppb}$ BC the simulated albedo decreases by an additional $\sim 0.003$ and $\sim 0.005$ per day during the same period. The albedo differ- ences in the presence of $\mathrm{BC}$ are partly compensated after the addition of fresh snow. The snowfall event on 30 January increases not only the absolute albedo values of the snowpack in all simulations, but the new snow layer simultaneously reduces the gap in the albedo caused by the different properties of the older, underlying snow. On longer timescales of weeks or months, the presence of $\mathrm{BC}$ in the snow causes a general reduction of the simulated albedo and an earlier melting of the snowpack.

Although the differences in the simulated albedo with different $\mathrm{BC}$ concentrations increase with the age of the snow as predicted by Warren and Wiscombe (1980), we attempt to quantify the average impact of $\mathrm{BC}$ on the snow albedo for typical conditions at Pyramid. We calculated averaged albedo values for several periods between 22 January 2005 and 30 March 2007 from simulations with different BC concentrations in the snow between 0 and 300 ppb. Figure 6 shows the normalized albedo as differences of the averaged albedo at certain BC concentrations minus the averaged albedo of pure snow. All selected periods are characterized by a continuous snowpack with a height of more than $10 \mathrm{~cm}$ in all simulations to exclude the impact of melting snow on the albedo. We tested if the length of the selected period is important and found that while the averaged albedo values are significantly higher during the period 12 to 17 March 2006 compared to the period 12 March to 5 May 2006, the sensitivity of the averaged albedo as a function of $\mathrm{BC}$ is essentially the same during both periods, at least for $\mathrm{BC}$ concentrations below 100 ppb (Fig. 6). A further comparison for the periods from 22 January to either 11 March 2005 or 8 April 2005 gave essentially the same values for the absolute as well as normalized albedo (not shown). For all periods, the relationship between normalized albedo and BC is best described using quadratic polynomials with regression coefficients $R^{2}$ between 0.989 and 0.998 . The fit demonstrates the nonlinear behavior of the albedo with respect to the $\mathrm{BC}$ concentration in the snow, because adding $\mathrm{BC}$ to the snow exerts a decreasing effect on the snow albedo with increasing $\mathrm{BC}$ concentrations. This behavior corresponds to the applied radiative transfer theory of Warren and Wiscombe (1980) because the $\mathrm{BC}$ already present captures some of the solar radiation that the additional $\mathrm{BC}$ otherwise would receive. Overall the albedo reductions remain small, ranging from 0.012 to 0.034 (average 0.027 ) and 0.031 to 0.078 (average 0.060 ) for $\mathrm{BC}$ concentrations of 100 and $300 \mathrm{ppb}$. The changes are similar to the values of Yasunari et al. (2013) who estimated reductions in snow albedo between 0.012 and 0.022 after the addition of $120 \mathrm{ppb}$ BC.

The sensitivity of the albedo towards $\mathrm{BC}$ depends further on the season with the smallest impact on the snowpack in December 2006 and the strongest in the March to May 2006 period. The seasonal dependence of the sensitivity is linked to the radiation intensity, which is lowest in December and increases until June, and the positive feedback between BC, snow temperature, grain size, and albedo as described above. 
Table 1. Snowpack properties for 23 and 31 January 2005, simulated with the upgraded model including radiative transfer and with different BC concentrations.

\begin{tabular}{llrrr}
\hline & & $\mathrm{BC}=0$ & $\mathrm{BC}=100 \mathrm{ppb}$ & $\mathrm{BC}=300 \mathrm{ppb}$ \\
\hline 23/01/2005 & Snow height $[\mathrm{cm}]$ & 52.8 & 52.6 & 52.4 \\
12:00 & SWE $[\mathrm{cm}]$ & 5.66 & 5.64 & 5.64 \\
& $T_{\text {snowpack }}\left[{ }^{\circ} \mathrm{C}\right]^{\mathrm{a}}$ & -13.3 & -13.2 & -13.0 \\
& $T_{10 \mathrm{~cm}\left[{ }^{\circ} \mathrm{C}\right]^{\mathrm{b}}}$ & -24.1 & -23.9 & -23.7 \\
& Grain diameter $[\mu \mathrm{m}]^{\mathrm{a}}$ & 301 & 303 & 305 \\
$31 / 01 / 2005$ & Snow height $[\mathrm{cm}]$ & 33.6 & 32.4 & 31.1 \\
$12: 00$ & SWE $[\mathrm{cm}]$ & 5.51 & 5.45 & 5.41 \\
& $T_{\text {snowpack }}\left[{ }^{\circ} \mathrm{C}\right]^{\mathrm{a}}$ & -10.3 & -9.7 & -9.8 \\
& $T_{10 \mathrm{~cm}\left[{ }^{\circ} \mathrm{C}\right]^{\mathrm{b}}}$ & -12.3 & -11.7 & -11.7 \\
& ${\text { Grain diameter }[\mu \mathrm{m}]^{\mathrm{a}}}$ & 369 & 386 & 400 \\
\hline
\end{tabular}

${ }^{a}$ SWE-weighted average for the entire snowpack. ${ }^{b}$ SWE-weighted average for the top $10 \mathrm{~cm}$ of the snowpack.

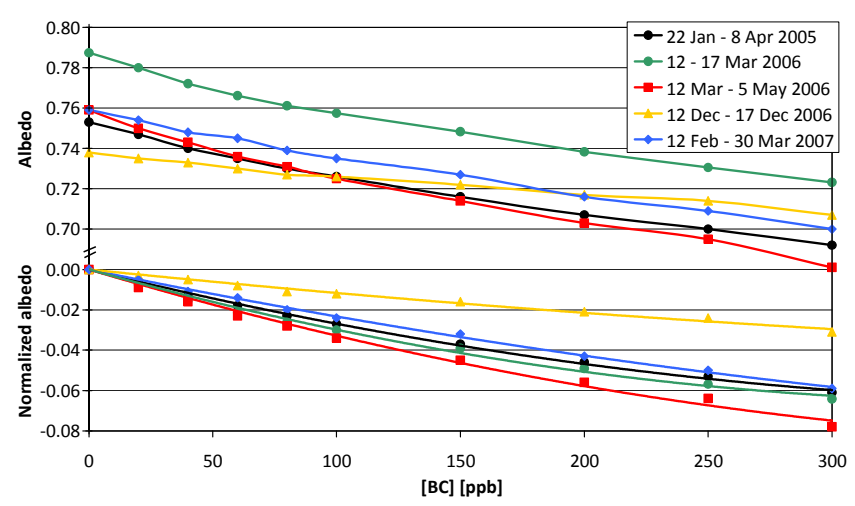

Figure 6. Top: simulated average albedo for several periods with continuous snow higher than $10 \mathrm{~cm}$ as a function of BC concentration. Bottom: normalized albedo as differences of the averaged albedo minus the averaged albedo at $\mathrm{BC}=0$. The lines correspond to the best fit of a quadratic polynomial forced through zero for each set of the normalized albedo.

\subsection{Impact of $\mathrm{BC}$ and dust on snow melting}

Although the overall impact of $\mathrm{BC}$ in the snow on the albedo remains limited, the impact on the melting of the snow can be rather large in the Himalayas as demonstrated in several model studies (e.g., Flanner et al., 2007; Ménégoz et al., 2014). In the presence of BC, the melting of the winter snowpack (corresponding to the longest period with a simulated continuous snowpack of a height of $>2 \mathrm{~cm}$ ) is shifted to early dates compared to the simulations without BC. This shift corresponds to 3 to 10 days in the presence of $100 \mathrm{ppb} \mathrm{BC}$ and increases to 17 to 27 days with $300 \mathrm{ppb} \mathrm{BC}$ for the 3 simulated years (Fig. 7). The relationship between the melting date and the $\mathrm{BC}$ concentrations is not always linear and depends for example on the timing of the precipitation events during springtime. If the winter snowpack does not persist until these events, a fast shift in the melting date is observed.
One example is the shift of 5 days of the melting in the season 2006/2007 if the BC is increased from 80 to $100 \mathrm{ppb}$. Besides the impact of the meteorological conditions, the number of days with snow on the ground steadily decreases with increasing BC concentrations. While this decrease shows a relatively large interannual variability, the overall trend is similar in all 3 years with a stronger impact of an incremental increase of $\mathrm{BC}$ at higher concentrations compared to lower concentrations in the snow. This behavior is, thus, in contrast to the direct effect of $\mathrm{BC}$ on the snow albedo, which is strongest at low concentrations and becomes weaker at higher concentrations (Fig. 6).

Although we did not measure the dust concentration in the surface snow samples, we can assume that dust was also present as previously observed in ice cores from the Himalayas (Thompson et al., 2000; Kaspari et al., 2011; Ginot et al., 2014). To study the impact of dust, we performed calculations with a constant dust concentration of $10 \mathrm{ppm}$, corresponding to the average observed in the Mera ice core (Ginot et al., 2014) and BC concentrations varying between 0 and $150 \mathrm{ppb}$ and additional calculations without $\mathrm{BC}$, but with dust concentrations up to $15 \mathrm{ppm}$. In all simulations, the addition of absorbing impurities like BC and dust leads to a reduction of the snow-covered periods. On average the snowcovered period is reduced by $5.6 \times 10^{-2}$ days (ppb BC) $)^{-1}$ and $7.6 \times 10^{-4}$ days (ppb dust) ${ }^{-1}$. The impact of the addition of $\mathrm{BC}$ increases strongly in the presence of $10 \mathrm{ppm}$ dust compared to pure snow because in these simulations the reduction is enhanced to $8.6 \times 10^{-2}$ days (ppb BC) $)^{-1}$. The reduction in the snowpack duration is on average $50 \%$ stronger compared to the simulations with only BC. This behavior is similar to the acceleration of the melting of the snow at higher $\mathrm{BC}$ concentrations. A linear regression, using only the results for the simulations without dust and $80 \mathrm{ppb} \leq \mathrm{BC} \leq 250 \mathrm{ppb}$ in Fig. 7, leads to a reduction of $7.9 \times 10^{-2}$ days $(\mathrm{ppb} B C)^{-1}$ and is, thus, similar to the impact obtained with a constant dust concentration of $10 \mathrm{ppm}$. Obviously, the influence of the 

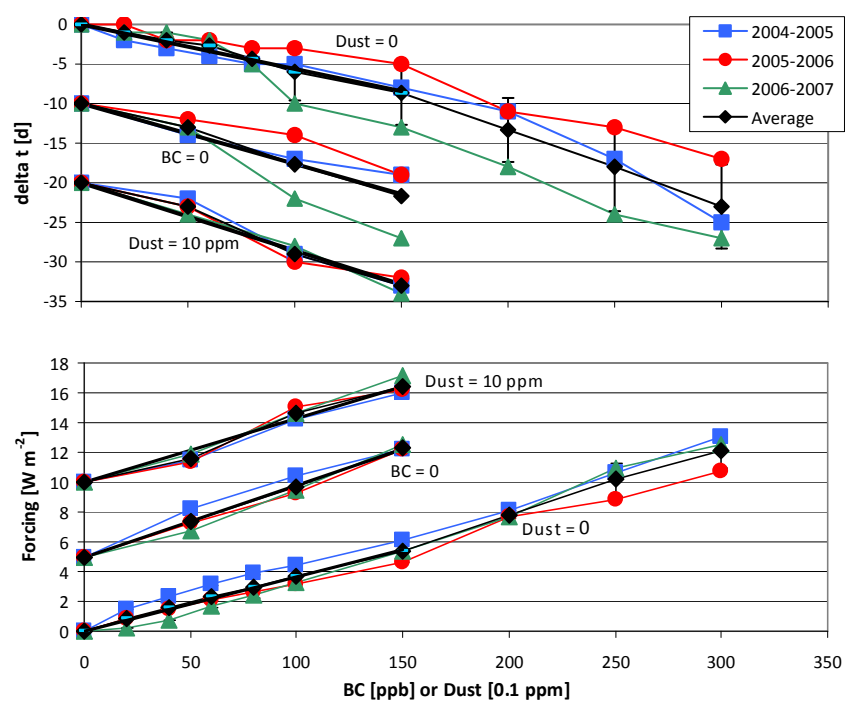

Figure 7. Top: reduction in the snow-covered period in days, simulated for different BC and dust concentrations in the snow. Bottom: simulated annual radiative forcing related to shortwave radiation due to the presence of $\mathrm{BC}$ and dust in the snow. Simulations are performed without dust, without $\mathrm{BC}$ (shifted by -10 days or $+5 \mathrm{~W} \mathrm{~m}^{-2}$ ), and with dust $=10 \mathrm{ppm}$ (shifted by -20 days or $+10 \mathrm{~W} \mathrm{~m}^{-2}$ ). In the last case, the reductions are calculated relative to the case with $\mathrm{BC}=0$ and dust $=10 \mathrm{ppm}$. Black symbols indicate the 3-year averages of the radiative forcing with the error bars representing the standard deviation. Black lines correspond to linear regressions forced through the origin for the average values for $\mathrm{BC}$ $\leq 150 \mathrm{ppb}$.

two different absorbing impurities in the model is comparable and exerts the same processes and modifications of the snowpack. As a result, $100 \mathrm{ppb} \mathrm{BC}$ and $7.5 \mathrm{ppm}$ dust can be regarded as equivalent in the model with respect to the melting of the snowpack. This relationship depends of course on the optical properties of the $\mathrm{BC}$ and dust used in the simulations and can vary since the optical properties of dust depend on the chemical composition.

\subsection{Radiative and net forcing}

The reduction of the snow albedo and the earlier melting of the snowpack leads to a radiative forcing because a larger proportion of the incoming radiation is absorbed at the Earth's surface. We calculated the radiative forcing using the observed incoming shortwave radiation and the simulated albedo of the snowpack. In the absence of snow, we used a soil albedo of 0.15 , corresponding to the observed wintertime albedo without snow on the ground (Fig. 3). All values for the radiative forcing are calculated as the difference in absorbed shortwave radiation with and without absorbing impurities in the snow. Since the radiative forcing can partly be compensated by latent and sensible heat fluxes due to an increased sublimation or evaporation of the snow, a net forcing is cal- culated after considering these fluxes between the snow and the atmosphere. However, no further feedback mechanisms between the snow and the atmosphere are included because all simulations were driven by the same meteorological data sets.

The calculated radiative (Fig. 7) and net forcing (Fig. S4) show similar, but opposite trends compared to the reduction in snow-covered periods. A reduction of the snow-covered period leads to increased radiative forcing due to the longer exposition of the underlying soil. This effect becomes obvious in the seasonal cycle of the simulated forcing, with $100 \mathrm{ppb} \mathrm{BC}$ in the snow shown as an example in Fig. 8. The maximum monthly radiative and net forcing are simulated for the end of the snow-covered period (i.e., May in 2004/2005 and 2005/2006 and April in 2006/2007). A large interannual variability in the forcing is apparent for the annual mean as well as in the seasonal cycle. For example, with $100 \mathrm{ppb} \mathrm{BC}$, the net forcing varied for the 3 simulated years by $\pm 1 \mathrm{~W} \mathrm{~m}^{-2}$, while the average forcing remains around $3 \mathrm{~W} \mathrm{~m}^{-2}$. An even larger variability becomes apparent in the seasonal cycle (Fig. 8). In April and May, the minimum and maximum forcing can vary between less than 3 and more than $25 \mathrm{~W} \mathrm{~m}^{-2}$. In contrast, at the beginning of the snow-covered period the forcing due to the presence of absorbers remains below $5 \mathrm{~W} \mathrm{~m}^{-2}$ and is relatively constant during the 3 simulated years. Several factors contribute to the interannual variability like differences in the incoming radiation and the length and timing of the snow-covered period (Fig. 8). However, Fig. 8 also demonstrates that the incoming shortwave radiation is not the major driver for the interannual variability, because in April the largest forcing is observed in the year 2006/2007 while the incoming shortwave radiation was smaller compared to the 2 preceding years. Therefore, the seasonality of the forcing is mainly driven by the timing of the snowfall and the melting of the snow. If solid precipitation occurs early in the winter season like in the simulations for 2006/2007, a forcing can also occur in the period from October to December, which may be comparable or even larger than the forcing calculated for March or April.

The simulated annual mean of the forcing due to the presence of $100 \mathrm{ppb} \mathrm{BC}$ for the 3 years of simulation corresponds to 3 to $4.5 \mathrm{~W} \mathrm{~m}^{-2}$ for the radiative forcing (Fig. 7) and 2 to $4 \mathrm{~W} \mathrm{~m}^{-2}$ for the net forcing (Fig. S4). In the presence of $10 \mathrm{ppm}$ dust the values increase to 6 to $7 \mathrm{~W} \mathrm{~m}^{-2}$ and 5.5 to $7 \mathrm{~W} \mathrm{~m}^{-2}$ for the radiative and net forcing. This range corresponds to the detected BC in snow concentrations. Due to the uncertainties in the measurements (see Methods) the correct $\mathrm{BC}$ concentrations could be a factor of 3 higher. With $300 \mathrm{ppb} \mathrm{BC}$, the radiative and net forcing increases to 10.5 to 13 and 9 to $12.5 \mathrm{~W} \mathrm{~m}^{-2}$.

Using the range of detected $\mathrm{BC}$ in snow concentrations $(\leq 100 \mathrm{ppb})$, the radiative forcing obtained with the local model is similar to results from previous global model runs. For example, Flanner et al. (2007) and Ménégoz et al. (2014) have reported annual means of the radiative forcing due to 


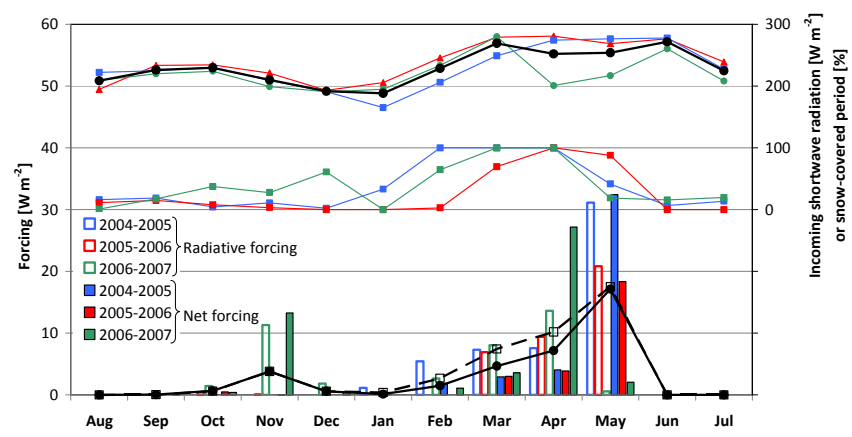

Figure 8. Simulated monthly mean radiative (open bars) and net forcing (filled bars) for the seasons 2004/2005 (blue), 2005/2006 (red), and 2006/2007 (green) due to the presence of $100 \mathrm{ppb}$ of BC in the snow. Black open squares and filled circles indicate 3-year averages of the monthly means of the radiative and net forcing. Also shown are snow-covered periods in percent based on the simulations without $\mathrm{BC}$ in the snow (middle) and the monthly means of the observed incoming shortwave radiation (top) for the 3 years. The black circles in the top panel indicate the 3-year average of the monthly means of the incoming radiation.

BC for the Himalayas and the Tibetan Plateau around 3.5 to 4 and 1 to $4 \mathrm{~W} \mathrm{~m}^{-2}$. These calculations included either no feedbacks (Flanner et al., 2007) or only short adjustments neglecting long-term feedbacks like changes of atmospheric circulation or sea surface temperature (Ménégoz et al., 2014). Ménégoz et al. (2014) also included dust in the snow, while Flanner et al. (2009) calculated that the addition of dust increases the total radiative forcing during springtime by 1 to $2 \mathrm{~W} \mathrm{~m}^{-2}$ in the considered region. However, in both studies the simulated annual averages of the $\mathrm{BC}$ in snow concentrations ranged from 100 to $200 \mathrm{ppb}$. Since a comparable radiative forcing was obtained with higher $\mathrm{BC}$ in snow concentrations, it can be concluded that the sensitivities are lower in the global models compared to our local model. Because the approach to represent the radiative transfer in the snowpack is similar or even the same in all three models, a major reason for the lower sensitivity could be the simplified representation of the snow in the global models, which describe the entire snowpack with a limited number of layers (Flanner et al., 2007; Ménégoz et al., 2014). As a result, the energy budget and the snow temperature profiles may not be well described leading to a bias in the simulation of the snow aging in the presence of the absorbers and of the melting of the snow. Moreover, the coarse spatial resolution of the models does not allow representing the specific local conditions at NCO-P.

Using a further global model, Kopacz et al. (2011) found $\mathrm{BC}$ in snow concentrations around $46 \mathrm{ppb}$ in October in the Mt. Everest region. Using simple estimates of the relationship between BC in snow and albedo, they derived an average radiative forcing of $9 \mathrm{~W} \mathrm{~m}^{-2}$ for October with monthly means ranging from 7.5 to $12 \mathrm{~W} \mathrm{~m}^{-2}$. While the simulated
$\mathrm{BC}$ in snow concentrations are more reasonable (although still too high), the applied sensitivities are high compared to our simulations for NCO-P and do not reflect the complex processes occurring in the snowpack.

\section{Conclusions}

The time series of $\mathrm{rBC}$ concentrations in the surface snow in the upper Khumbu Valley reported here indicates a seasonal cycle with maximum concentrations in the pre-monsoon period and low concentrations during the monsoon period. This cycle directly reflects the behavior of atmospheric $\mathrm{BC}$ in the same high-altitude region (Marinoni et al., 2010) and is also conserved in ice cores from nearby glaciers (Ginot et al., 2014). Therefore, ice cores can be used to reconstruct historic $\mathrm{BC}$ concentrations in these regions. Unfortunately, a large uncertainty remains regarding the absolute $\mathrm{BC}$ in snow concentrations. While the SP2 technique delivers precise concentrations of $\mathrm{rBC}$, the melting of the snow samples during transport and storage potentially modified the detected concentrations. This effect probably contributed to discrepancies between the snow concentrations reported here, compared to previously reported results for EC, while the two different techniques also added to the mismatch (Lim et al., 2014). Further measurements are needed to resolve these discrepancies and to determine actual concentrations. Such accurate data are urgently needed for the validation of global and regional models used to calculate the impact of $\mathrm{BC}$ in snow on the regional climate (Qian et al., 2011; Ménégoz et al., 2014). While models simulating the impact of $\mathrm{BC}$ in snow on albedo and radiative forcing for a given snowpack exist, the quantification is currently mostly hampered by the uncertainty in BC in snow concentrations.

In its first application to the snowpack in the Himalayas, the standard Crocus model reveals significant discrepancies compared to observations with a large positive bias in the simulation of the snow-covered period and the albedo. While the Crocus model is well adapted to conditions in the Alps and gives satisfying results in polar regions (Jacobi et al., 2010; Brun et al., 2011; Vionnet et al., 2012), the high radiation intensities in the Himalayas make the model obviously more vulnerable due to the simplified parameterization of the albedo. While simulations were performed for typical conditions at Pyramid, it is likely that this simulated bias can be expected for wider regions of the high-altitude area of the Himalayas. This concerns the simulation of the thin seasonal snowpack with a large contrast in albedo between the snow-free and snow-covered ground. The bias in the standard Crocus model is probably diminished in regions with the formation of a thicker snowpack like in the Western Himalayas (Ménégoz et al., 2013a) and in calculations over glaciers where the underlying firn and ice exhibit a higher albedo than the soil. Furthermore, the parameterization of the ground heat fluxes in the Crocus model may not be well 
adapted to the conditions of the Himalayas, possibly contributing to the overestimation of the snowpack especially late and early in the winter season.

The positive bias in the albedo and the snowpack simulations are reduced with the upgraded Crocus model, taking into account the radiative transfer in the snow. This improvement becomes obvious even in simulations without absorbing impurities. The results are further enhanced if $\mathrm{BC}$ in the snow is considered and varied in a range constraint by surface snow and previous ice cores measurements (Ginot et al., 2014). Nevertheless, even in these simulations, the albedo of and the length of the period with the seasonal snowpack remain well overestimated. Since the simulations were all performed with constant $\mathrm{BC}$ concentrations, any enrichment of $\mathrm{BC}$ at the snow surface or in specific layers due to sublimation, dry deposition, melting, and refreezing (Doherty et al., 2013) is not included. Nevertheless, even in the model runs with $\mathrm{BC}$ concentrations of $300 \mathrm{ppb}$, which is more than 3 -fold the maximum detected $\mathrm{BC}$ concentration in the surface snow as well as the ice core from this region (Ginot et al., 2014), the snowpack is more persistent than observed. Thus, even if any or all of the post-depositional processes leads to an enrichment of more than a factor of 3 throughout the snowpack, differences in the simulations and the observations would remain. Stronger enrichments of BC in certain layers, like reported previously for the Mera glacier (Kaspari et al., 2014) or in the Arctic (Doherty et al., 2013), appear unlikely because they should have been detected in our surface snow samples or in the Mera ice core (Ginot et al., 2014). Moreover, the observed maxima of $B C$ concentrations in the snow can easily be explained by dry deposition alone without invoking any further enrichment processes (Yasunari et al., 2013). These results do not rule out that higher BC in snow concentrations are encountered under different conditions like on glaciers or even higher altitudes, where the snowpack may not melt before April, when the air masses with the highest concentrations in BC finally arrive at the high-altitude region (Fig. 2).

A heterogeneous distribution of absorbing compounds within the snowpack may induce stronger temperature gradients inside the snowpack, further accelerating the snow metamorphism compared to a snowpack with homogeneous concentrations as assumed in our simulations. Variable concentrations can be caused by processes during the melting of the snowpack as described above. Since the absorbing compounds are introduced by dry and wet deposition, concentration gradients inside the snowpack can be expected even in the not-melting snowpack. Moreover, these gradients can be different for different absorbing compounds. Vertical profiles of the absorbing compounds need to be determined to address this point. Whether it can also have a profound impact on the snowpack simulations remains to be seen and will be the subject of further studies.

The simulations with the Crocus model reveal further that dust and probably also other absorbers play a strong role not only for the snow albedo itself, but also for the impact of $\mathrm{BC}$. While the impact of a given amount of an absorber on the snow albedo diminishes in the presence of further impurities, this is the opposite case for the increase of snow-free days and the radiative forcing. Here, the simulations demonstrate that the presence of other absorbers like dust even enhances the effect of BC. Therefore, the role of dust in the snow, together with the role of $\mathrm{BC}$, needs to be studied in the future, and a correct determination of dust and its properties parallel to the determination of $\mathrm{BC}$ in the snow is needed. Organic absorbers in the snow (Wang et al., 2013) may also play a role similar to dust and should also be considered in further studies. In summary, a full characterization of all absorbing compounds and their different contributions seems necessary to study the full impact of these compounds on the snow albedo and further related snow properties and processes.

Finally, this study concentrated only on the effect of the albedo for the snowpack simulations. Other processes parameterized in the snow model (e.g., turbulent fluxes, ground heat flux, snow metamorphism, liquid water formation, percolation) and uncertainties in the forcing data may also contribute to differences between simulations and observations. Further detailed observations are needed to improve future snowpack simulations in this sensitive region. This mainly concerns direct observations of the total and solid precipitation, which are crucial parameters in snowpack and hydrological modeling for this sensitive region.

\section{The Supplement related to this article is available online at doi:10.5194/tc-9-1685-2015-supplement.}

Acknowledgements. This work was supported by the "Agence Nationale de la Recherche" under contracts ANR-09-CEP-00501/PAPRIKA, ANR-09-CEP-005-02/PAPRIKA, ANR 2011 Blanc SIMI 5-6 021 04, and by the Investissements d'avenir Labex OSUG@2020 under grant ANR10 LABX56. The authors thank EvK2CNR and the Nepalese technical staff of Pyramid Laboratory, the SHARE (Stations at High Altitude for Research on the Environment) project, and the Nepal Academy of Science and Technology. S. Lim acknowledges a government scholarship by the Korean Ministry of Education and Science Technology.

Edited by: A. Klein

\section{References}

Bonasoni, P., Laj, P., Marinoni, A., Sprenger, M., Angelini, F., Arduini, J., Bonafè, U., Calzolari, F., Colombo, T., Decesari, S., Di Biagio, C., di Sarra, A. G., Evangelisti, F., Duchi, R., Facchini, MC., Fuzzi, S., Gobbi, G. P., Maione, M., Panday, A., Roccato, F., Sellegri, K., Venzac, H., Verza, GP., Villani, P., Vuillermoz, 
E., and Cristofanelli, P.: Atmospheric Brown Clouds in the Himalayas: first two years of continuous observations at the Nepal Climate Observatory-Pyramid (5079 m), Atmos. Chem. Phys., 10, 7515-7531, doi:10.5194/acp-10-7515-2010, 2010.

Bond, T. C. and Bergstrom, R. W.: Light absorption by carbonaceous particles: An investigative review, Aerosol Sci. Technol., 40, 27-67, 2006.

Bond, T. C., Doherty, S. J., Fahey, D. W., Forster, P. M., Berntsen, T., DeAngelo, B. J., Flanner, M. G., Ghan, S., Kärcher, B., Koch, D., Kinne, S., Kondo, Y., Quinn, P. K., Sarofim, M. C., Schultz, M. G., Schulz, M., Venkataraman, C., Zhang, H., Zhang, S., Bellouin, N., Guttikunda, S. K., Hopke, P. K., Jacobson, M. Z., Kaiser, J. W., Klimont, Z., Lohmann, U., Schwarz, J. P., Shindell, D., Storelvmo, T., Warren, S. G., and Zender, C. S.: Bounding the role of black carbon in the climate system: A scientific assessment, J. Geophys. Res., 118, 1-173, 2013.

Brun, E., Martin, E., Simon, V., Gendre, C., and Coleou, C.: An energy and mass model of snow cover suitable for operational avalanche forecasting, J. Glaciol., 35, 333-342, 1989.

Brun, E., David, P., Sudul, M., and Brunot, G.: A numerical model to simulate snow-cover stratigraphy for operational avalanche forecasting, J. Glaciol., 38, 13-22, 1992.

Brun, E., Six, D., Picard, G., Vionnet, V., Arnaud, L., Bazile, E., Boone, A., Bouchard, A., Genthon, C., Guidard, V., Le Moigne, P., Rabier, F., and Seity, Y.: Snow/atmosphere coupled simulation at Dome C, Antarctica, J. Glaciol., 52, 721-736, 2011.

Carrico, C. M., Bergin, M. H., Shrestha, A. B., Dibb, J. E., Gomes, L., and Harris, J. M.: The importance of carbon and mineral dust to seasonal aerosol properties in the Nepal Himalaya, Atmos. Environ., 37, 2811-2824, 2003.

Doherty, S. J., Grenfell, T. C., Forsström, S., Hegg, D. L., Brandt, R. E., and Warren, S. G.: Observed vertical redistribution of black carbon and other insoluble light-absorbing particles in melting snow, J. Geophys. Res., 118, 5553-5569, 2013.

Duchi, R., Cristofanelli, P., Marinoni, A., Bourcier, L., Laj, P., Calzolari, F., Adhikary, P., Verza, G.-P., Vuillermoz, E., and Bonasoni, P.: Synoptic-scale dust transport events in the southern Himalayas, Aeolian Res., 13, 51-57, 2014.

Etchevers, P., Martin, E., Brown, R., Fierz, C., Lejeune, Y., Bazile, E., Boone, A., Dai, Y.-J., Essery, R., Fernandez, A., Gusev, Y., Jordan, R., Koren, V., Kowalczyk, E., Nasonova, N. O., Pyles, R. D., Schlosser, A., Shmakin, A. B., Smirnova, T. G., Strasser, U., Verseghy, D., Yamazaki, T., and Yang, Z.-L.: Validation of the energy budget of an alpine snowpack simulated by several snow models (SnowMIP project), Ann. Glac., 38, 150-158, 2004.

Flanner, M. G., Zender, C. S., Randerson, J. T., and Rasch, P. J.: Present-day climate forcing and response from black carbon in snow, J. Geophys. Res., 112, D11202, doi:10.1029/2006JD008003, 2007.

Flanner, M. G., Zender, C. S., Hess, P. G., Mahowald, N. M., Painter, T. H., Ramanathan, V., and Rasch, P. J.: Springtime warming and reduced snow cover from carbonaceous particles, Atmos. Chem. Phys., 9, 2481-2497, doi:10.5194/acp-9-24812009, 2009.

Flanner, M. G., Liu, X., Zhou, C., Penner, J. E., and Jiao, C.: Enhanced solar energy absorption by internally-mixed black carbon in snow grains, Atmos. Chem. Phys., 12, 4699-4721, doi:10.5194/acp-12-4699-2012, 2012.
Ginot, P., Dumont, M., Lim, S., Patris, N., Taupin, J.-D., Wagnon, P., Gilbert, A., Arnaud, Y., Marinoni, A., Bonasoni, P., and Laj, P.: A 10 year record of black carbon and dust from a Mera Peak ice core (Nepal): variability and potential impact on melting of Himalayan glaciers, The Cryosphere, 8, 1479-1496, doi:10.5194/tc-8-1479-2014, 2014.

Hansen, J. and Nazarenko, L.: Soot climate forcing via snow and ice albedos, Proc. Natl. Acad. Sci. 101, 423-428, 2004.

Immerzeel, W. W., van Beek, L. P. H., and Bierkens, M. F. P.: Climate change will affect the Asian Water Towers, Science, 328, 1382-1385, 2010.

Jacobi, H.-W., Domine, F., Simpson, W. R., Douglas, T. A., and Sturm, M.: Simulation of the specific surface area of snow using a one-dimensional physical snowpack model: implementation and evaluation for subarctic snow in Alaska, The Cryosphere, 4, 35-51, doi:10.5194/tc-4-35-2010, 2010.

Kääb, A., Berthier, E., Nuth, C., Gardelle, J., and Arnaud, Y.: Contrasting patterns of early 21 st century glacier mass change in the Himalaya, Nature, 488, 495-498, 2012.

Kaspari, S. D., Schwikowski, M., Gysel, M., Flanner, M. G., Kang, S., Hou, S., and Mayewski, P. A.: Recent increase in black carbon concentrations from a Mt. Everest ice core spanning 1860-2000 AD, Geophys. Res. Lett., 38, L04703, doi:10.1029/2010GL046096, 2011.

Kaspari, S., Painter, T. H., Gysel, M., Skiles, S. M., and Schwikowski, M.: Seasonal and elevational variations of black carbon and dust in snow and ice in the Solu-Khumbu, Nepal and estimated radiative forcings, Atmos. Chem. Phys., 14, 80898103, doi:10.5194/acp-14-8089-2014, 2014.

Kopacz, M., Mauzerall, D. L., Wang, J., Leibensperger, E. M., Henze, D. K., and Singh, K.: Origin and radiative forcing of black carbon transported to the Himalayas and Tibetan Plateau, Atmos. Chem. Phys., 11, 2837-2852, doi:10.5194/acp-11-28372011, 2011.

Krinner, G., Boucher, O., and Balkanski, Y.: Ice-free glacial northern Asia due to dust deposition on snow, Clim. Dyn., 27, 613625, 2006.

Lau, K.-M. and Kim, K.-M.: Observational relationships between aerosol and Asian monsoon rainfall, and circulation, Geophys Res. Lett., 33, L21810, doi:10.1029/2006GL027546, 2006.

Lejeune, Y., Bertrand, J.-M., Wagnon, P., and Morin, S.: A physically based model of the year-round surface energy and mass balance of debris-covered glaciers, J. Glaciol., 59, 327-344, 2013.

Lim, S., Faïn, X., Zanatta, M., Cozic, J., Jaffrezo, J.-L., Ginot, P., and Laj, P.: Refractory black carbon mass concentrations in snow and ice: method evaluation and inter-comparison with elemental carbon measurement, Atmos. Meas. Tech., 7, 3307-3324, doi:10.5194/amt-7-3307-2014, 2014.

Marinoni, A., Cristofanelli, P., Laj, P., Duchi, R., Calzolari, F., Decesari, S., Sellegri, K., Vuillermoz, E., Verza, G. P., Villani, P., and Bonasoni, P.: Aerosol mass and black carbon concentrations, a two year record at NCO-P (5079 m, Southern Himalayas), Atmos. Chem. Phys., 10, 8551-8562, doi:10.5194/acp-10-85512010, 2010.

Ménégoz, M., Gallée, H., and Jacobi, H. W.: Precipitation and snow cover in the Himalaya: from reanalysis to regional climate simulations, Hydrol. Earth Syst. Sci., 17, 3921-3936, doi:10.5194/hess-17-3921-2013, 2013a. 
Ménégoz, M., Krinner, G., Balkanski, Y., Cozic, A., Boucher, O., and Ciais, P.: Boreal and temperate snow cover variations induced by black carbon emissions in the middle of the 21 st century, The Cryosphere, 7, 537-554, doi:10.5194/tc-7-537-2013, 2013b.

Ménégoz, M., Krinner, G., Balkanski, Y., Boucher, O., Cozic, A., Lim, S., Ginot, P., Laj, P., Gallée, H., Wagnon, P., Marinoni, A., and Jacobi, H. W.: Snow cover sensitivity to black carbon deposition in the Himalayas: from atmospheric and ice core measurements to regional climate simulations, Atmos. Chem. Phys., 14, 4237-4249, doi:10.5194/acp-14-4237-2014, 2014.

Ming, J., Cachier, H., Xiao, C., Qin, D., Kang, S., Hou, S., and $\mathrm{Xu}, \mathrm{J}$.: Black carbon record based on a shallow Himalayan ice core and its climatic implications, Atmos. Chem. Phys., 8, 1343 1352, doi:10.5194/acp-8-1343-2008, 2008.

Ming, J., Xiao, C., Cachier, H., Qin, D., Qin, X., Li, Z., and Pu, J.: Black Carbon (BC) in the snow of glaciers in west China and its potential effects on albedos, Atmos. Res., 92, 114-123, 2009.

Moteki, N. and Kondo, Y.: Effects of mixing state on black carbon measurements by laser-induced incandescence, Aerosol Sci. Technol., 41, 398-417, 2007.

Moteki, N. and Kondo, Y.: Dependence of laser-induced incandescence on physical properties of black carbon aerosols: Measurements and theoretical interpretation, Aerosol Sci. Technol., 44, 663-675, 2010.

Negi, H. S. and Kokhanovsky, A.: Retrieval of snow grain size and albedo of western Himalayan snow cover using satellite data, The Cryosphere, 5, 831-847, doi:10.5194/tc-5-831-2011, 2011.

Painter, T. H., Barrett, A. P., Landry, C. C., Neff, J. C., Cassidy, M. P., Lawrence, C. R., McBride, K. E., and Farmer, G. L.: Impact of disturbed desert soils on duration of mountain snow cover, Geophys. Res. Lett., 34, L12502, doi:10.1029/2007GL030284, 2007.

Qian, Y., Flanner, M. G., Leung, L. R., and Wang, W.: Sensitivity studies on the impacts of Tibetan Plateau snowpack pollution on the Asian hydrological cycle and monsoon climate, Atmos. Chem. Phys., 11, 1929-1948, doi:10.5194/acp-11-19292011, 2011.

Ramanathan, V., Li, F., Ramana, M. V., Praveen, P. S., Kim, D., Corrigan, C. E., Nguyen, H., Stone, E. A., Schauer, J. J., Carmichael, G. R., Adhikary, B., and Yoon, S. C.: Atmospheric brown clouds: Hemispherical and regional variations in long-range transport, absorption, and radiative forcing, J. Geophys. Res., 112, D22S21, doi:10.1029/2006JD008124, 2007.

Salerno, F., Guyennon, N., Thakuri, S., Viviano, G., Romano, E., Vuillermoz, E., Cristofanelli, P., Stocchi, P., Agrillo, G., Ma, Y., and Tartari, G.: Weak precipitation, warm winters and springs impact glaciers of south slopes of Mt. Everest (central Himalaya) in the last 2 decades (1994-2013), The Cryosphere, 9, 12291247, doi:10.5194/tc-9-1229-2015, 2015.

Schwarz, J. P., Gao, R. S., Fahey, D. W., Thomson, D. S., Watts, L. A., Wilson, J. C., Reeves, J. M., Darbeheshti, M., Baumgardner, D. G., Kok, G. L., Chung, S. H., Schulz, M., Hendricks, J., Lauer, A., Kärcher, B., Slowik, J. G., Rosenlof, K. H., Thompson, T. L., Langford, A. O., Loewenstein, M., and Aikin, K. C.: Single-particle measurements of midlatitude black carbon and light-scattering aerosols from the boundary layer to the lower stratosphere, J. Geophys. Res., 111, D16207, doi:10.1029/2006jd007076, 2006.
Shrestha, M., Wang, L., Koike, T., Xue, Y., and Hirabayashi, Y.: Modeling the spatial distribution of snow cover in the Dudhkoshi region of the Nepal Himalayas, J. Hydrometeorol., 13, 204-222, 2012.

Stocker, T. F., Qin, D., Plattner, G. K., Tignor, M., Allen, S. K. Boschung, J., Nauels, A., Xia, Y., Bex, V., and Midgley, P. M. (Eds.): Climate Change 2013: The Physical Science Basis. Contribution of Working Group I to the Fifth Assessment Report of the Intergovernmental Panel on Climate Change, Cambridge University Press, Cambridge, UK and New York, NY, 1535 pp., 2013.

Thompson, L. C., Yao, T., Mosley-Thompson, E., Davis, M. E., Henderson, K. A., and Lin, P.-N.: A high-resolution millennial record of the South Asian Monsoon from Himalayan ice cores, Science, 289, 1916-1929, 2000.

Tyagi, A. and Pai D. S. (Eds.): Monsoon Report 2011, IMD Met Monograph Synoptic Meteorology No. 01/2012, National Climate Centre, India Meteorological Department, Pune, India, 178 pp., 2012.

Tyagi, A., Mazumdar, A. B., and Pai D. S. (Eds.): Monsoon Report 2009, IMD Met Monograph Synoptic Meteorology No. 09/2010, National Climate Centre, India Meteorological Department, Pune, India, 159 pp., 2010.

Tyagi, A., Mazumdar, A. B., and Pai D. S. (Eds.): Monsoon Report 2010, IMD Met Monograph Synoptic Meteorology No. 10/2011, National Climate Centre, India Meteorological Department, Pune, India, 210 pp., 2011.

Vionnet, V., Brun, E., Morin, S., Boone, A., Faroux, S., Le Moigne, P., Martin, E., and Willemet, J.-M.: The detailed snowpack scheme Crocus and its implementation in SURFEX v7.2, Geosci Model Dev., 5, 773-791, doi:10.5194/gmd-5-773-2012, 2012.

Wang, X., Doherty, S. J., and Huang, J.: Black carbon and other light-absorbing impurities in snow across Northern China, J. Geophys. Res., 118, 1471-1492, 2013.

Warren, S. G. and Wiscombe, W. J.: A model for the spectral albedo of snow. II: Snow containing atmospheric aerosols, J. Atmos. Sci., 37, 2734-2745, 1980.

Wiscombe, W. J. and Warren, S. G.: A model for the spectral albedo of snow, I: Pure snow, J. Atmos. Sci., 37, 2712-2733, 1980.

$\mathrm{Xu}, \mathrm{B}$., Yao, T., Liu, X., and Wang, N.: Elemental and organic carbon measurements with a two-step heating-gas chromatography system in snow samples from the Tibetan Plateau, Ann. Glaciol., 43, 257-262, 2006.

Xu, B., Cao, J., Hansen, J., Yao, T., Joswia, D. R., Wang, N., Wu, G., Wang, M., Zhao, H., Yang, W., Liu, X., and He, J.: Black soot and the survival of Tibetan glaciers, P. Natl. Acad. Sci., 106, 22114-22118, 2009.

Yasunari, T. J., Tan, Q., Lau, K.-M., Bonasoni, P., Marinoni, A., Laj, P., Ménégoz, M., Takemura, T., and Chin, M., Estimated range of black carbon dry deposition and the related snow albedo reduction over Himalayan glaciers during dry pre-monsoon periods, Atmos. Environ., 78, 259-267, 2013. 